DOI: 10.2478 /ausp-2020-0024

\title{
Rendering Science Fiction, Culture, and Language While Translating Ready Player One
}

\author{
Attila IMRE \\ Department of Applied Linguistics, Târgu-Mureş \\ Sapientia Hungarian University of Transylvania (Cluj-Napoca, Romania) \\ Faculty of Technical and Human Sciences \\ attilaimre@ms.sapientia.ro
}

\begin{abstract}
The amazing science fiction setting and plot depicted by Ernest Cline in his Ready Player One may constitute a real challenge to translators and subtitlers alike as his book was also turned into a movie by Steven Spielberg. We have collected hundreds of terms from the original book (2011), its Hungarian translation (2012), the Hungarian dubbed version (March 2018), the most popular Hungarian fansub (2018), and the professional subtitle (July 2018, from the same person who translated the script for the dubbing). Having classified the collected terms into various categories, we have managed to identify successful Hungarian renditions of cultural allusions from the 1980s (movies, books, videogames, shows, songs, characters, objects, vehicles, etc.).
\end{abstract}

Keywords: science fiction, translation, subtitling, Hungarian, titles

\section{Introduction}

The revolution and evolution of technology resulted in the evolution and constant rise of translation, which diversified and reached industrial scales. More than that, some of its latest branches, such as videogame localization and audiovisual translation, have become so popular due to their links to the entertainment industry that this symbiosis already threatens the independent existence of translation.

While professional associations keep trying to raise the status of translators by creating and reshaping ethical codes, they also face the challenge of defining basic terms within the industry, such as professional, certified, expert versus amateur, non-professional, fansubber, etc. As the growing popularity of globally available audiovisual products (movies, TV series, documentaries) has led to substantially reduced production time of dubbed versions and subtitles, in the majority of cases viewers hardly care about the source if good-quality dubbings and subtitles 
accompany their favourite shows the moment they are available online via specific service providers (such as $H B O$ Go or Netflix) or can be downloaded from various sites.

In our view, Ernest Cline's Ready Player One (2011) managed to become one of the most popular books of the 2010s, which was taken further by turning it into a movie (2018), involving the author as one of the screenplay writers and Steven Spielberg as director. ${ }^{1}$ The immense popularity is also due to the topic as it is about videogames set in a science fiction environment stemming from the present-day reality and near-future tendencies.

Our aim is to discuss possible challenges while translating either the book version or the subtitle; the main objective is to discuss various terms (e.g. technical, military, acronyms) collected from the book and its movie version (dubbing, subtitle, and fansub), exemplifying both correct and poor cases.

Being labelled a science fiction book, we should offer a few definitions of science fiction first. Science fiction (SF) may have many definitions, ranging from interpreting "science" and "fiction" in this respect to others differentiating it from fantasy. The list below contains definitions from famous SF authors:

- "that branch of literature which deals with the reaction of human beings to changes in science and technology" (Isaac Asimov 1975/1981, qtd. in Blackford 2017: 8);

- "realistic speculation about possible future events, based solidly on adequate knowledge of the real world, past and present, and on a thorough understanding of the nature and significance of the scientific method" (Robert Heinlein 1959); ${ }^{2}$

- "We have a fictitious world; that is the first step: it is a society that does not in fact exist, but is predicated on our known society; ... our world transformed into that which it is not or not yet.... this is the essence of science fiction, the conceptual dislocation within the society so that as a result a new society is generated in the author's mind” (Philip K. Dick 1981, qtd. in Tolley 2010: 42);

- "the fiction of revolutions. Revolutions in time, space, medicine, travel, and thought... Above all, science fiction is the fiction of warm-blooded human men and women sometimes elevated and sometimes crushed by their machines" (Ray Bradbury 1974, qtd. in Davin 2005: 271);

- "a charming romance intermingled with scientific fact and prophetic vision" (Hugo Gernsback 1926 in Gernsback et al. 1926: 3);

- "science fiction is something that could happen - but usually you wouldn't want it to. Fantasy is something that couldn't happen - though often you only wish that it could" (Clarke 2001, Foreword).

Scholars researching SF also label it with terms like "science”, "technology" or “simply fiction” and “speculation” (James-Mendlesohn 2003: 186), “other worlds”,

1 https://www.imdb.com/title/tt1677720/ (downloaded on: 01.28.2020).

2 http://sciencefiction.loa.org/biographies/heinlein_science.php (downloaded on: 01.28.2020). 
“the literature of 'what if'” (Evans 1988: 9), or the "exploration of possible worlds" (Haraway 1992: 300), which all seem to be key terms associated with SF.

In fact, Stableford observes that the combination of science and fiction is a “seemingly oxymoronic phrase" (Stableford 2006, Introduction: xxi), being certain that "the vast majority" of the texts labelled as SF had no respect for "the scientific method." The possible reason is offered by Robert J. Sawyer, who accepts that SF is "first and foremost, an entertainment medium, so we have to allow some latitude to tell the stories” (qtd.in Grazier-Cass 2017: 18), being supported by Wood as well: "science fiction is a story about contact with other worlds and imaginary science and technology" (Wood 2017: 114). Finally, SF is a "literature of ideas" (JamesMendlesohn 2003: 149), "the literature of progress", and hence it is politically "essentially liberal” (James-Mendlesohn 2003: 231).

While the definitions presented above are all justified, we may easily find problems with all definitions:

1. Asimov's definition is too vague, not even mentioning the (near)future.

2. Heinlein oversees the fact that a solid foundation of the real world is often neglected, which is why some may combine science fiction with fantasy.

3. Philip K. Dick does not reflect on the fact that the fictitious world is often rooted in the present, and there may be no new society whatsoever.

4. Bradbury highlights that revolutions may trigger sci-fi scenarios, yet they remain fiction as machines may destroy humans.

5. Gernsback is rather optimistic as he mixes romance, science, and prophecy, while rather few science fiction masterpieces contain all these ingredients.

6. Macleod's remarks are rather politically oriented, while it is questionable whether authors of SF create for political reasons.

7. Clarke offers a rather simple, yet important difference between science fiction and fantasy, enabling us to take SF as describing possible scenarios (in the near or distant future, often bleak ones), while fantasy offers a completely impossible but not always a desired world; it is also important to add that high fantasy presents alternative worlds, where we typically witness a good versus evil clash, making it closer to science fiction.

A possible conclusion why all these definitions are troublesome is that the authors had in mind particular examples of works labelled as science fiction. While they all contain true facts about science fiction, a more general definition may be necessary: science fiction primarily presents possible or predictable future events, mostly from the perspective of human beings, who face important changes in their lives. A further description may include that these changes are predominantly technological, social, or political and may derive from technological (e.g. robots) or biological revolutions (e.g. "freaks" with special skills) as well as encounters/clashes with other civilizations (with either dire or promising consequences for humans). 
Once started as a genre of fiction, literature relying on imagination combined with science and technology offers entertainment for millions of readers. Although SF as a genre stemmed from literature, today it is a huge part of the movie and videogame industry as well: many SF books or videogames have been turned into movies.

It is also true that while SF works are often set in the future, some of them may return to the past, discussing a different scenario compared to the one that actually happened, or time travels to a different past, commonly referred to as "alternate worlds" deriving from the previously mentioned "what-if" scenarios. Besides, earlier SF works imagined as future are already past or present, such as Orwell's 1984, correctly observed by Orson Scott Card. ${ }^{3}$ Travelling to other planets (worlds) may not necessarily have a future storyline, but they still contradict some "known or supposed law of nature" (time travels). ${ }^{4}$

For a long time, readers or viewers of SF have been prepared to learn about the following major "themes": resurrecting extinct species, artificial intelligence, living on other worlds, travelling through time (faster than light speed), searching for aliens (Wood 2017: 5), which directly contribute to a "setting [that] differs from our own world", which is supposed to be explained "in scientific or rational, as opposed to supernatural, terms" (Prucher 2007: 171).

The fact that in many cases SF foreshadows a possible future is clearly exemplified by SF masterpieces. An illustrious example is Huxley's Brave New World mentioning cloning in 1932, and then the cloned Dolly comes into being in 1996. Another example getting us closer to the topic is Arthur C. Clarke's The City and the Stars written in 1958, in which "completely immersive, life-like videogames are played" (Wood 2017), knowing that virtual reality headsets have been available since 2015, which is also present in Cline's Ready Player One (2011), where videogame players use visors and haptic gloves to sense virtual reality as real.

The popularity of SF may be easily explained if we approach it as primarily part of the entertainment industry. Home entertainment is getting more and more homogeneous, due to globalization, which may be perceived as a "product" of the technical revolution: "A complex web of social processes that intensify and expand worldwide economic, cultural, political and technological exchanges and connections" (Campbell et al. 2010: 4). The constantly shrinking costs of SF-related products (books, videogames, movies, TV series) have led to the mass-consumption of SF, ${ }^{5}$ with millions of fans worldwide. There is no denying that the large number of fans access their favourite SF products via localized versions (videogames), dubbing

3 https://www.writersdigest.com/writing-articles/by-writing-goal/get-published-sell-my-work/ defining-science-fiction-and-fantasy (downloaded on: 01.28.2020).

4 Ibid.

5 The $20^{\text {th }}$-century SF was much less popular but also characterized by "obsessive followers ... forming a community" (Stableford 2006: 465). 
or subtitling, expecting high-quality work as many of them can - to a certain extent compare the localized version with the original, predominantly English one.

The strengthening and diversification of SF works resulted in various schools, such as cyberpunk (Clute-Nicholls 1993: 288) with a dystopian future, globally controlled information networks, biological engineering and virtual reality, hallmarked by William Gibson's Neuromancer (1984), portraying “young, streetwise, aggressive, alienated and offensive” people (hence “punk”). Later on, growing anxiety is visible with the spread of information technology, climate change, deadly viruses, and harmful artificial intelligence, all based on the fear that the "human component" is eternal: in many cases, the real cause of trouble is human greed and lust for power, even if alien intervention may be suspected (e.g. 2001: A Space Odyssey, cf. Booker 2006: 75).

The development of visual media enabled famous directors to adapt ambitious SF books to screen, creating a cult and exploiting the financial possibilities, best exemplified with Star Wars (cf. Stableford 2006: 468). Today, SF is a well-established and "respectable area of scholarship" (James Gunn), knowing that the top ten bestgrossing films of all time are predominantly SF or fantasy, and approximately two thousand books of SF and fantasy are published each year (James-Mendlesohn 2003, Foreword: XVIII). At such a large scale, both authors and directors of SF works may become celebrated stars, resulting in bestsellers and highest rankings on dedicated sites (e.g. imdb.com), and Ernest Cline stands for this type of author, successfully embedding the virtual reality of videogames into a dystopian near-future.

Our research focuses on the Hungarian version of Ready Player One, including the book, the dubbed version, and the subtitle as well, compared to the original works, discussing possible challenges and consequences of the translations. Thus, the next section deals with the evolution of the translation industry.

\section{The translation industry}

Due to constraints of space and the purpose of our research, we only mention that translation per se has grown into an industry triggered by the evolution of technology, enabling large crowds to handle technological challenges of modern translations, namely audiovisual translations (AVT), successfully.

In Gouadec's terms, the age of "PRAT, or Pencil and Rubber-Assisted Translator" is "on the way out" and the "Computer-Assisted Translator has taken over" (Gouadec 2007: 109), which has made it possible for virtually all translators to use term bases (TB) and translation memories (TM). However, the most dynamic and developing branches of translation industry seem to be subservient to the entertainment industry, and the reduced time to produce dubbed versions and subtitles may easily be to the detriment of quality translations seeking ever higher profits in the target countries. 
Dubbing and subtitling are the two most popular types of AVT (Díaz Cintas 2008: 1); dubbing needs a crew of specialists (technicians, voice actors, etc.), while subtitling may be pursued as a single-person hobby, giving rise to millions of fansubbers worldwide. Subtitling has torn many concepts and traditions associated with translation, such as "professional", "skilled”, "experienced", or "financial reward", and created new ones such as fansubbing, crowdsourcing, volunteering, to mention but a few. Although the consequences are widely discussed, including changes in professional ethics and status of translators (Imre 2019a), we only focus on the possible impact translators may have on the target language and culture with their work.

The issue is worth discussing as a prospective translator of a SF book or movie may not know its possible impact at the time of translation, but it is sure that a bestseller or blockbuster will create resounding waves, which is why all translators should have in mind quality assurance, whatever it takes. From this perspective, we cannot consider "professional" translators only those ones who have obtained a certificate or formal education in translation studies as the number of "untrained" or "uneducated" translators largely exceeds the certified ones.

In fact, we witness the rise of non-professional interpreters and translators (NPIT) worldwide, starting from a 2012 conference, ${ }^{6}$ and there are studies proving that fansubs do not automatically refer to poor quality as they are highly motivated and have direct access to the audiovisual material. It is also known that they may be only appreciated if their viewers enjoy their work, and thus they are forced to know the needs of the public, which is why they are more target-driven, resulting in disrespecting the "traditions of translation".

As such, we tend to believe that cultural references and linguistic examples of the "official" and "non-official" Hungarian versions will display certain differences (e.g. political correctness, SF terminology, slang, and taboo). Although NPIT research studies support the idea that "translating is a quasi-universal human capability and activity" taking forms of crowdsourcing, church/military/court/ medical interpreting, they also accept that literary and scientific translations need expert translators (Harris 2017: 29-43). What we found innovative is the definition of "expert translator", which label may be attained either "by formal training" or "by mentorship" (Harris 2017: 34). In the following, we will present some findings about the level of expertise of Hungarian versions for Ready Player One.

\section{Translating Ready Player One}

Ready Player One (2011) is a highly popular SF book written by Ernest Cline, and all plot descriptions mention that it celebrates geek/nerd status, where everybody

6 https://www.npit5.com/ (downloaded on: 01.29.2020). 
plays videogames in virtual reality, relying on countless pop culture references of the 1980s. During the ultimate game, ${ }^{7}$ which is the primary concern of all people, virtual reality offers hope and, anyway, "[g]oing outside is highly overrated” (Ernest Cline). The Hungarian translation (HT) by Gábor Roboz was published in 2012 (Cline 2012).

The success of the original book has led to a movie adaptation as well, directed by Steven Spielberg, being released in 2018, enabling us to compare the Hungarian dubbed version (D), produced by Mafilm Audio Kft. (translated by Tamás Tóth, 09.03.2018), ${ }^{8}$ with two Hungarian subtitles: the fan subtitle (fansub) translated by Csaba Szász (F) shortly after the release of the movie and the professional subtitle created by Tamás Tóth (S), whose version appeared later than the dubbing and the fansub. ${ }^{9}$

The storyline offers certain categories for those looking for the quality of translations, such as scientific terms, videogame terms, taboo and swear words, acronyms, and the cultural adaptations of the impressive number of names (characters) and titles of various books, movies, videogames, TV shows, and songs referred to in the book and movie versions. When creating the database for these entries, we could not help not remembering the very first words of the editors of The Cambridge Companion to Science Fiction: "Science fiction is at the intersection of numerous fields. It is a literature which draws on popular culture, and which engages in speculation about science, history and all types of social relations" (James-Mendlesohn 2003).

The quote warns the potential translators that linguistic skills are not enough to delve into translating SF as general "world knowledge" is vital (similarly to other translations as well), completed with the knowledge of famous previous SF works as well, including the terminology (especially neologisms created by former authors) of various areas connected to major SF themes mentioned previously. For instance, it is worth checking a collection of canonized SF books. ${ }^{10}$ Even if experts in the field, translators may face various challenges, admits James Womack, as translating SF and fantasy is "particularly difficult in general... it is a genre that is constantly wrong-footing the reader, and so your work as a translator is initially affected by your being wrong-footed as a reader ... a lot of the handholds that you have with straight-down-the-line realist fiction just don't exist". ${ }^{11}$

Thus, the following expectations seem to be sensible regarding SF: a considerable number of scientific/technical or scientific-looking terms (a number of which abbreviated or acronyms) some of which having nothing to do with reality, and the setting is typically in the future, but reference is made to the past as well.

7 https://carturesti.ro/carte/ready-player-one-9454008 - a book presentation by Andreea Manaila (downloaded on: 02.15.2020).

8 http://iszdb.hu/index.php?szinkron=25204 (downloaded on: 02.15.2020).

9 https://www.feliratok.info/index.php?fid=584642 (downloaded on: 01.28.2020).

10 https://www.goodreads.com/shelf/show/sci-fi-canon (downloaded on: 02.16.2020).

11 http://weirdfictionreview.com/2016/08/translating-strange-science-fiction/ (downloaded on: 02.16.2020). 
The linguistic approach to translated SF works is expected to reveal that expert translators (trained ones) will follow written and unwritten norms more than fansubbers, who wish to be "trendy" enough to obtain high rates for their subtitles (e.g. when using BS Player subtitling).

We have created a term base of close to 500 entries, selected from the books (B and HT), Hungarian dubbing (D), the professional subtitle (S), and the fansub (F), which were classified into various categories, detailed in the following sections.

\subsection{Videogames and technical terms}

Specific terminology helps creating the proper setting for the storyline, and translators must choose carefully the terms to render the original atmosphere. However, this might be really challenging, as confessed by Marian Womack: "one can only hope to be as faithful as possible. And feeling that you are finally 'embodying' an author's voice is rewarding." 12

Almost half of the collected terms may be labelled as technical or belonging to the videogames mentioned or played as part of the plot. A few relevant examples are listed below:

(1) omnidirectional treadmill (B, M)

Hu. mindenirányú futógép (HT), mindenirányú futópad (HS, D, F)

(2) avatar (B, M, S)

Hu. avatár (HT, HS, D, F)

(3) Shaptic Bootsuit, full-body haptic feedback suit (B)

X1 haptic bootsuit, bootsuit (M)

haptic chair/suit, haptics (B, M), (S)

Hu. Shaptic Bootsuit, haptikus feedback ruha (HT)

X1-es haptikus bootruha, bootruha (HS, D, F)

haptikus szék (HT), haptikus cucc (HS, D, F)

(4) visor (B), full visor (M)

Hu. vizor, látómező (HT), szemüveg (HS), VR-szemüveg (D, F)

(5) $\operatorname{artifact}(\mathrm{B}, \mathrm{M})$

Hu. mágikus tárgy (HT), varázstárgy (HS, D, F)

(6) (to) hack (B, M)

Hu. feltör, meghekkel (HT), betör az egységébe, hackel (HS)

betör a cuccba (D), feltöri az egységet (F)

(7) immersion rig $^{13}$

12 Ibid.

13 A rig is a comfortable armchair fitted with a visor and haptic gloves; accessing the simulation "with a new state-of-the-art immersion rig, it was almost impossible to tell the OASIS from reality” (Cline 2011: 27). 
Hu. egység (HS, D, F)

(8) drone (B, M)

Hu. drón (HS, D, F)

(9) force field (B, M)

$\mathrm{Hu}$. energiamező (HT), energiapajzs (HS, D, F)

(10) visual field (M)

Hu. látómezó (HT), látótér (HS, D, F)

(11) live feed (B, M)

Hu. élő felvétel, közvetítés, videoadás, adás (HT), élő adás (HS, D, F)

(12) being broadcast (B, M)

Hu. élóben rögzít (HT), élóben közvetít (HS, D, F)

The examples show that certain terms are standardized in translation (avatár, feltör), while others are neologisms enough to have different variants (e.g. futópad, futógép), waiting for a commonly established equivalent term. Some English terms may have two Hungarian variants, one reflecting the phonetic transcript, while the other being borrowed and suffixed (to hack 'hekkel' and 'hackel'). ${ }^{14}$ Interestingly, drone does not appear in the HT, while we could not trace visual field in the original book.

However, we found a whole batch of technical terms not present in the original work (thus missing from the HT as well), while the movie and Hungarian versions contain many of them:

(13) tapeworm program

$\mathrm{Hu}$. féregprogram (HS, D, F)

(14) quadraphonic

Hu. kvadrofon (HS, D), kvadrofónikus (F)

(15) microfiber crotch inlay

Hu. mikrószálas betét (HS, D, F)

(16) pressure-sensitive underlay

Hu. nyomásérzékelő (HS, D, F)

(17) emotion-suppressing software

$\mathrm{Hu}$ érzelemtompító szoftver (HS, D, F)

(18) Snowcat

Hu. hójáró (HS, D, F)

(19) pod

Hu. kabin (HS, D, F)

(20) loyalty pod

Hu. behajtózárka (D, F)

14 Strange as it may seem, there are many Hungarian fansubs using the verb hackle, e.g. in Bones. 
A possible reason for more technical terms in the movie may be the visual support for various gadgets enhancing the SF setting. While some of these terms may be considered as neologisms (Shaptic Bootsuit), the most important and interesting term (187 book occurrences) in this respect is gunter, referring to a Halliday's Easter Egg hunter. As this is a completely new term in this respect, ${ }^{15}$ we would have expected either the full borrowing of the term in Hungarian or the creation of a new word reflecting the roots. The Hungarian translation for egg hunter is tojásvadász, so - by analogy - it could have been sadász.

Instead, the Hungarian translation is nyest 'marten' (used 191 times during the translation), which is a rodent hunting for eggs as well. Although close, it is not the best option, and the dubbed version and subtitles use the same term, which diminishes the specific SF atmosphere created by Cline.

We know how powerful such terms may become, such as cyberspace (William Gibson Neuromancer), robotics (Karel Čapek-Isaac Asimov 1941), or Big Brother (George Orwell 1984). We tend to think that gunter is a term with a possibly similar impact. Although it is challenging to coin a new term while translating, expert translators should think about the impact in case the original work or translation goes global and becomes an instant worldwide success. In these cases, a single term may be the one through which an entire story, book, or movie is identified.

However, there are two more terms strictly connected to gunters, having the same root:

(21) Oology Division, oologist (B, M)

Hu. tojástan, oológia (HT), oológus (HS, D, F)

It is visible that explicitation is only used in the translation, while the other versions rely on the context although the term is rather scientific, known from real life, referring to the study of bird eggs. Cline "endows" the term with a new meaning as Halliday's Easter Egg hunters are gunters (mostly freelancers) and oologists (corporate researchers or players).

Military terms

As SF is often about various conflicts, military terms are expected to appear. In our case, for instance, the battle scene in the end offers a few military terms:

(22) Squadron (B, M)

Hu. szakasz (D), raj (F)

(23) Railgun (B, M)

Hu. mágnespuska (HT), sínágyú (S, D, F), mágnesfegyver (Eraser, 1996)

15 Although one might find Gunter's line or Gunter's scale after Edmund Gunter (1581-1628) online, this has little to do with the future time setting of the storyline. 
(24) Anti-personnel ordinance cannon! (M)

Hu. Személy elleni tüzérségi löveg! (S, D, F)

(25) If you reach up with your left hand at 11 o'clock. (M)

Hu. Ha bal kézzel felnyúlsz 11 óra irányába. (S, D, F)

(26) Nine o'clock and three o'clock. (M)

Hu. Kilenc és három óránál. (S, D, F)

Before discussing the terms, we would like to offer a relevant quote in this respect: "In the military we have our own language that isn't understood by most civilians. Terminology, acronyms, processes for waging war... these all seem to be alien if not translated into civilian English." ${ }^{16}$ We created a possible mind map of the US Army, including branches of service, equipment, ranks, commands, evaluation of commands and military tactics (Imre 2018: 170), and the examples listed belong to either equipment (weapons) or military tactics (cf. army time, Imre 2019b: 125).

A squadron may refer to either cavalry, tanks or similar, subdivided into troops, but it may refer to aviation or naval unit as well. ${ }^{17}$ The book is more explicit, mentioning a squadron of Sixer gunships (aviation), and the HT offers osztag 'squad(ron)'. In Example 22, the Hungarian subtitle omits the phrase, while the dubbing and fan subtitle offers two variants, both of them acceptable (referring to a small group of soldiers).

Example 23 is visibly more challenging, as the HT uses adaptation ('magnet' + 'rifle', which is similar to the term in the Hungarian subtitle of the original movie, Eraser, 1996: 'magnet' + 'gun'); the common S, D, and F variant makes no sense as it is the calque version of the original. There are Hungarian sources discussing how nonsense the Hungarian term is, ${ }^{18}$ suggesting to preserve the original or simply refer to it as ágyú 'cannon'.

Example 24 is most probably an invented movie term, not present in the book. As such, the Hungarian versions created a term that is the combination of a calque and an established equivalent, which sounds a little exaggerated.

The last two examples ( 25 and 26) are specifically used in military contexts, and, while these references are not present in the books, the visual support enables the viewers to understand them. However, they are not used in a Hungarian context, so they seem artificial, offering a word-for-word sense; it would have been much more natural to use balra 'to your left' and jobbra 'to your right'.

16 A Master Sergeant (US Army); https:/www.rallypoint.com/answers/what-is-military-culture (downloaded on: 09.09.2018).

17 https://en.wikipedia.org/wiki/Squadron (downloaded on: 01.29.2020).

18 E.g. https://www.facebook.com/leiterjakab/posts/10155470607677439/ (downloaded on: 01.29.2020). 


\subsection{Measurements}

Another typical challenge might be the adaptation or conversion of various measurements (length, weight, money value, etc.). Expert translators know that the translation, subtitle, or dubbing is for the target readers and viewers, thus converting them and "rounding" them up or down should be automatic:

(27) 50-foot (M)

Hu. húszméteres (S, D), 15 méteres (F)

(28) every six feet

Hu. kétméterenként (S, D, F)

(29) 10 feet

Hu. közelében (S), mellett (D), három méterre (F)

(30) trillionaire (M, on the magazine cover), multibillionaire (B)

Hu. milliárdos $(\mathrm{S}, \mathrm{D})$, trilliomos $(\mathrm{F})$

(31) half a trillion

Hu. félbillió (S, D), fél trillió (F)

(32) twenty-thou (M)

Hu. 20 rugó (S, D), 20 kiló (F)

The conversion in these cases is justified as translators would like to offer senseful variants. We can see that Example 27 refers to length: technically speaking, 50 feet is $15.24 \mathrm{~m}$, and thus the fansub is much closer as the dubbing and the subtitle mention $20 \mathrm{~m}$, which indicates that they used the "round-up" technique (knowing that so-called "round" numbers are easier to remember). Example 28 is identical in all three translations (technically $1.8288 \mathrm{~m}$ ), and Example 29 offers three variants: the first two mean that 'close by' or 'next to', while the fansub means 'at 3m', which is correct.

The issue in examples 30 and 31 is manifold. First, trillion means $10^{18}$, but English-speaking countries use this term for $10^{12}$. The former term is not used in a Hungarian context, so the dubbing/subtitle is correct, while the fan subtitle offers a word-for-word translation, which is rather bombastic.

Example 32 is a slang term for 22,000 , which is nicely adapted by using two different Hungarian slang terms for thousand: rugó and kiló.

\subsection{Acronyms}

It is known that abbreviations and acronyms constitute a real challenge in various areas (scientific, technical, legal, medicine, military, etc.) although in this case they are kept to the minimum: 
(33) OASIS

(34) IOI

(35) Aech, $H$

(36) USPS (M)

Hu. postai furgon (S, D, F)

The first acronym is used the most times in the book (350 times in the original and 349 times in the translation), while the movie used it 44 times (subtitle: 40, fan subtitle: 43). While the book deciphers it twice (Ontologically Anthropocentric Sensory Immersive Simulation), the Hungarian translation does it only once (Ontológiailag Antropometrikus Szenzorikus Immerzív Szimuláció), and then the acronym is used systematically. Interestingly, there is no explanation in the dubbing or subtitles what the acronym stands for, which is anyway 61 characters with spaces, and it is irrelevant for the plot; all we need to know that it is the platform for the online multiplayer game.

The second example is used 137 times in the book and the Hungarian translation as well, referring to the Innovative Online Industries (major Internet service provider), which is mentioned in the movie (25 times), dubbing, and subtitles as well (more than 20 times), without translation.

Example 35, $H$, is the first letter of the character's name, which appears in its phonetic version in the book (Aech), but only as $H$ in the translations.

The last example is not present in the book, but it appears in the movie, and all three Hungarian versions are identical, which may be explained if the fansub was inspired by the previously appeared dubbing.

\subsection{Titles and names}

The greatest challenge of Cline's work is arguably the impressive number of titles and names, most of them referring to the pop culture of the end of the $20^{\text {th }}$ century: movies, videogames, shows, songs, artist, protagonists, books, etc.

There are countless dedicated sites offering so-called full lists of all cultural references in the book and the movie, ${ }^{19}$ but this is near impossible, having in mind even gestures from famous movies (e.g. Terminator 2, "thumbs up" scene). ${ }^{20}$ Nevertheless, these references offer a good cultural quiz for fans reading or watching the movie, to the general amusement of the older generation. ${ }^{21}$

19 https://www.scifi.hu/2018/04/05/giga-lista-a-ready-player-one-pop-kulturalis-utalasairol/ (downloaded on: 01.16.2020).

20 www.comingsoon.net (downloaded on: 01.16.2020).

21 https://readyplayerone.fandom.com/wiki/Ready_Player_One_(film) (downloaded on: 01.16.2020). 
The translators and subtitlers are faced with a real challenge in this chapter as they should create a similarly recognizable atmosphere with words and hints for the target public, to which the only option is to offer those names and titles that were once used for the original works released in Hungary. After all, the public should gain a feeling of connoisseur by recognizing many hints, knowing that Cline and Spielberg have built in many previous successes from various works of entertainment, including Spielberg's own. We managed to collect around 340 references for anime, comic books, movies, songs, musicians, bands, TV shows, videogames, and contemporary items (e.g. food, drink).

The first challenge is the title itself. It is the message the player reads when logging into OASIS (Ready Player One), which is so important that neither the book translator nor the dubbers and subtitlers dared to change, even if it is translated in the book once (Egyes játékos, készülj!) (Cline 2012: 38). However, titles, similarly to names, are often preserved to offer an air of foreignness, loyal to Venuti's foreignizing approach (Venuti 2004). But this is a rather complex special case, when the title is turned into an icon for the plot, as the letters are formed into a maze, ${ }^{22}$ leading to an Easter egg: ${ }^{23}$

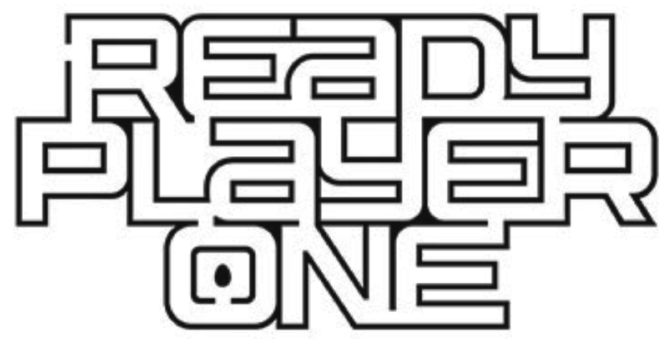

Figure 1. Logo and maze

Movie and game titles or famous characters, vehicles should be preserved; unless when released in Hungary they were translated, turning to established equivalents:

- Robotron, Aliens, Mayhem Mansion, Nancy Drew, Adventure, Mario Kart, GoldenEye, Oddjob, Ptifall, Swordquest, and Thriller are not translated, being movies or videogames marketed under the same name.

- Animal House (Party zóna), The Shining (Ragyogás), ${ }^{24}$ The Breakfast Club (Nulladik óra), The Dark Crystal (A sötét kristály), and The Fly (A légy) are translated, being famous in Hungary with dubbed versions, while the fansub knows that Ferris Bueller's Day Off was marketed in Hungary as Meglógtam a Ferrarival, the subtitle uses the original English title.

22 https://www.funkopopnews.com/2018/03/09/walmart-exclusive-antique-parzival-funko-pop (downloaded on: 01.16.2020).

23 https://io9.gizmodo.com/theres-an-easter-egg-hidden-in-the-ready-player-onemov-1797395680 (downloaded on: 01.16.2020).

24 Even if the subtitles and the dubbing use an extra definite article: A ragyogás. 
- The name of a restaurant is preserved in the subtitle and dubbing, while the fansub contains an error: instead of Chuck E Cheese we have Chucky's Cheese, which is a serious misinterpretation, given that a rather scary Chucky also appears in the movie (Child's Play 1988, notorious serial killer).

- The Distracted Globe is both in the book and movie; thus, the subtitle, dubbed version, and fansub use the same Hungarian term: a Dilis Glóbusz.

- Famous characters, such as Bruce Banner (Hulk), Peter Parker (Spider-Man), or Clark Kent (Superman), are preserved, relying on the general culture of the readers and viewers, similarly to famous vehicles (Millennium Falcon, Star Wars).

- Star Wars offers another key term, namely padawan ${ }^{25}$ (borrowed as padavan in Hungarian), which is preserved in the fansub, while padavan is used in the subtitle.

In the case of names, the predominant procedure is the use of loan words, reflecting Venuti's foreignizing strategy, knowing that there is no chance to mention that Arrakis is the famous planet from Frank Herbert's Dune, similarly to the Harkonnen Drop-Ship (with three different Hungarian versions, and only the subtitle version appears in the original book), ${ }^{26}$ or Planet Doom (Doom-bolygó) is a videogame.

To sum up this section, the translator and subtitlers managed to render the titles and names faithfully, even if they had to look for the established Hungarian equivalent, with a few exceptions.

\section{Conclusions}

Although the selected examples are varied, including the original book, the Hungarian translation, the original movie, and its Hungarian dubbing, subtitle, and a fansub, too, general conclusions are impossible to draw. However, the samples suggest that the fansub relied on the dubbed version here and there, exemplified below:

(37) It's a licensed skin over a standard frame. (M)

Hu. Fizetős skin, standard vázon. (D, S, F)

(38) The Sixer Fixer? (M)

Hu. Hatos-irtó? (D, S), Hatosírtó? (F)

(39) Wade Watts, if I catch you touching my stuff again, not joking... Out.

$\mathrm{Hu}$. Wade Watts, ha még egyszer hozzányúlsz a holmimhoz... Nem viccelek, eltünsz! (D, S)

Hu. Wade Watts, ha még egyszer hozzáérsz a cuccaimhoz... Nem viccelek, eltúnsz! (F)

25 A Jedi apprentice, cf. https://starwars.fandom.com/wiki/Padawan (downloaded on: 01.28.2020).

26 The variants in the dubbing and fansub are zealous renditions: Harkonnen szállítóhajó, Harkonnen beszerzó hajója ('cargo ship, freighter'). 
(40) Maintenance, report to loyalty pod 31-B. (M)

Hu. Karbantartót kérünk a 31-B kabinhoz. (D, S)

Hu. Karbantartót kérünk a 31-P kabinhoz. (F)

All four examples were selected from the movie, not appearing in the book. Example 37 is extremely unlikely to be translated similarly, Example 38 is a unique term, which first appeared in the dubbing, nowhere else, and the fansub even contains a spelling mistake (irtó and not írtó). Example 39 may possibly contain a pun, including the meaning of Wade Watts (to wade 'to wade through something with some effort'), ${ }^{27}$ while the last example may stem from the difficulty to overhear the sentence (the sonant $/ \mathrm{b} /$ is close to the aphonic $/ \mathrm{p} /$ ).

An overall strategy during translation is to loan as many English words as possible, for obvious reasons: globalization - more readers and viewers understand English, who might have already come into contact with these English words in previous books, movies, or videogames. Thus, preserving the English names, titles, or technical terms adds to the "feeling" of SF with top-notch gadgets mixed with English terms from an age when rules in the former East-European blocks were not so strict regarding the translation of various products and leaflets into the target language. Hence, there were many established equivalents detected (especially for movie titles and videogames), as the success of a movie starts from the title and its poster.

There were obvious differences between the book and the movie, partially due to copyright issues, but, interestingly, more technical terms were found in the movie version, which were successfully rendered into Hungarian. The translators and subtitlers of Ready Player One are faced with the immense crowds of fans worldwide, who can instantly spot whether or not the translators are experts in the field of books, movies, videogames, songs, or shows belonging to different genres and ages. Our conclusion is that, given the ever-shrinking time for producing high-quality translations and subtitles, the Hungarian version terms and phrases investigated are of good quality, with minor exceptions.

Although we have collected a large number of slang and taboo terms worth analysing, a further article is needed to properly discuss them.

\section{References}

Blackford, Russell. 2017. Science fiction and the moral imagination: Visions, minds, ethics. Springer.

Booker, M. Keith. 2006. Alternate Americas: Science fiction film and American culture. Westport, Conn: Praeger.

27 Cf. https://dictionary.cambridge.org/dictionary/english/wade (downloaded on: 01.29.2020). 
Campbell, Patricia J.-MacKinnon, Aran-Stevens, Christy R. 2010. An introduction to global studies. s. l.: Wiley-Blackwell.

Clarke, Arthur C. 2001. The collected stories of Arthur C. Clarke. New York: Tor Books.

Cline, Ernest. 2011. Ready Player One. New York: Crown Publishers. 2012. Ready Player One. (Transl. Gábor Roboz). Budapest: Agave Könyvek.

Clute, John-Nicholls, Peter. 1993. The encyclopedia of science fiction. New York: St Martin's Press.

Davin, Eric Leif. 2005. Partners in wonder: Women and the birth of science fiction, 1926-1965. Lexington Books.

Díaz Cintas, Jorge. 2008. Introduction. In: Díaz Cintas, J. (ed.), The didactics of audiovisual translation. John Benjamins Publishing Company. 1-18.

Evans, Christopher. 1988. Writing science fiction. London: A \& C Black.

Gernsback, Hugo et al. 1926. Amazing stories. Vol. 01/01. New York: Experimenter Publishing Co.

Gouadec, Daniel. 2007. Translation as a profession. John Benjamins Publishing.

Grazier, Kevin R. R.-Cass, Stephen. 2017. Hollyweird science: The next generation: From spaceships to microchips. New York: Springer.

Haraway, Donna. 1992. The promises of monsters: A regenerative politics for inappropriate/d others. In: Cultural studies. New York: Routledge. 295-337.

Harris, Brian. 2017. Unprofessional translation: A blog-based overview. In: Antonini, R.-Cirillo, L.-Rossato, L.-Torresi, I. (eds.), Non-professional interpreting and translation. John Benjamins Publishing Company. 29-43.

Imre, Attila. 2018. Military terminology in the subtitles of Band of Brothers. Acta Universitatis Sapientiae Philologica 10(3): 167-178.

2019a. A fordítók szakmai etikájának kihívásai [The ethical challenges of being a translator]. Tanulmányok [Studies] 2019/1: 147-160.

2019b. Amikor a feliratozó elalszik [When the subtitler falls asleep]. In: Nyomárkay, I.-Nagy, S. I. (eds.), A fordítás elméleti és gyakorlati kérdései. Budapest: Modern Filológiai Társaság. 115-32.

James, Edward-Mendlesohn, Farah (eds.), 2003. The Cambridge companion to science fiction. Cambridge-New York: Cambridge University Press.

Prucher, Jeff (ed.). 2007. Brave new words. Oxford: Oxford University Press.

Stableford, Brian. 2006. Science fact and science fiction. An encyclopedia. New York-London: Routledge.

Tolley, Michael J. 2010. The collected stories of Philip K. Dick. In: Broderick, D. (ed.), Skiffy and mimesis. More best of ASFR, Australian SF review. The Borgo Press. 41-83.

Venuti, Lawrence. 2004. The translator's invisibility: A history of translation. Routledge.

Wood, Matthew Brenden. 2017. The science of science fiction. Hartford: Nomad Press. 


\section{Web Sources}

http://iszdb.hu/index.php?szinkron=25204 (downloaded on: 02.15.2020).

http://sciencefiction.loa.org/biographies/heinlein_science.php (downloaded on: 01.28.2020).

https://carturesti.ro/carte/ready-player-one-9454008 (downloaded on: 02.15.2020). https://dictionary.cambridge.org/dictionary/english/wade (downloaded on: 01.29.2020).

https://en.wikipedia.org/wiki/Squadron (downloaded on: 01.29.2020).

https://esfs.info/2019/08/24/esfs-awards-2019/ (downloaded on: 02.15.2020).

https://io9.gizmodo.com/theres-an-easter-egg-hidden-in-the-ready-player-onemov-1797395680 (downloaded on: 01.16.2020).

https://readyplayerone.fandom.com/wiki/Ready_Player_One_(film) (downloaded on: 01.16.2020).

https://starwars.fandom.com/wiki/Padawan (downloaded on: 01.28.2020).

https://www.facebook.com/leiterjakab/posts/10155470607677439/ (downloaded on: 01.29.2020).

https://www.feliratok.info/index.php?fid=584642 (downloaded on: 01.28.2020).

https://www.funkopopnews.com/2018/03/09/walmart-exclusive-antique-parzivalfunko-pop/ (downloaded on: 01.16.2020).

https://www.goodreads.com/shelf/show/sci-fi-canon (downloaded on: 02.16.2020). https://www.imdb.com/title/tt1677720/ (downloaded on: 01.28.2020).

https://www.npit5.com/ (downloaded on: 01.29.2020).

https://www.rallypoint.com/answers/what-is-military-culture (downloaded on: 09.09.2018).

https://www.scifi.hu/2018/04/05/giga-lista-a-ready-player-one-pop-kulturalisutalasairol/ (downloaded on: 01.16.2020).

https://www.writersdigest.com/writing-articles/by-writing-goal/get-published-sellmy-work/defining-science-fiction-and-fantasy (downloaded on: 01.28.2020). www.comingsoon.net (downloaded on: 01.16.2020). 